\title{
Title: An estimate of the Bulk Silicate Earth potassium isotopic composition based on MC-ICPMS measurements of basalts
}

Authors: Kun Wang (王昆)* and Stein B. Jacobsen

\begin{abstract}
Affiliations:
Department of Earth and Planetary Sciences, Harvard University, 20 Oxford Street, Cambridge, MA 02138, USA.
\end{abstract}

* Correspondence author: kunwang@fas.harvard.edu

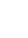

\section{Abstract:}

We report a method for high-precision potassium isotope measurements that improves by an order of magnitude the precision compared to previous methods. The purification of $K$ is achieved through ion exchange chromatography on AG50W-X8 cation exchange resins. The ${ }^{41} K /{ }^{39} K$ ratios are analyzed with a $G V$ Instruments IsoProbe $P$ Multiple-Collector Inductively Coupled Plasma Mass Spectrometer (MC-ICP-MS) equipped with a hexapole collision gas cell. With this technique, the argon-hydride interferences as well as the large ${ }^{40} \mathrm{Ar}^{+}$peak from the Ar-plasma are eliminated. The ${ }^{41} \mathrm{~K} /{ }^{39} \mathrm{~K}$ ratios can thus be obtained with a precision of 0.05 per mil. The precision and accuracy of this method is validated with gravimetrically determined ${ }^{41} \mathrm{~K}$ or ${ }^{39} \mathrm{~K}$ enriched standards. New precise $\mathrm{K}$ isotopic compositions of three terrestrial basalts (BCR-2, BHVO-1 and a MORB) are also reported. These basalts have indistinguishable $K$ isotopic compositions and are used to define a reference value of $-0.479 \pm 0.027$ per mil for the ${ }^{41} K /{ }^{39} \mathrm{~K}$ ratio of the Bulk Silicate Earth (BSE) relative to a Merck Suprapur potassium nitrate standard. Seawater and sylvites from evaporite deposits have similar ${ }^{41} K /{ }^{39} K$ ratios, but higher by up to 0.227 per mil compared to the Merck Suprapur standard. Other commercially available $K$-salts/solutions also have ${ }^{41} K /{ }^{39} K$ ratios similar to the Merck standard, while a SPEX K-chloride was higher by 0.384 per mil. This shows that $\mathrm{K}$ isotope variations will be useful as a tracer in low-temperature geochemistry processes. 


\section{Introduction:}

35 Terrestrial planets, such as the Earth, Moon, Mars and asteroid 4 Vesta, have long been known as depleted in volatile elements relative to CI meteorites and the bulk solar composition (Wasserburg et al., 1964). The cause of this volatile depletion in the inner Solar System is still not entirely known (cf. Humayun and Cassen, 2000; Halliday and Porcelli, 2001); it has been proposed to be related to processes such as the incomplete condensation of solar nebular materials or partial vaporization/condensation via giant impacts during the accretion stages of the Earth and other planetary bodies. Potassium is a moderately volatile element, and the ratio of $\mathrm{K}$ to a refractory element such as $\mathrm{U}$ has been used as a key index of this volatile depletion. For example, the $\mathrm{K} / \mathrm{U}$ ratio in the silicate Earth (13,800; Arevalo et al., 2009) is five-fold depleted compared to that in CI chondrites ( 70,000; Wasserburg et al., 1964; Anders and Grevesse, 1989); and the K/U ratio in the Moon (2,500; Taylor, 1982) is even more than five times depleted relative to that in the silicate Earth. This depletion of $\mathrm{K}$ and other volatile elements is one of the fundamental characteristics of the bulk chemistry of the Earth, Moon and other inner solar system bodies (such as Mars, 4 Vesta and Angrite Parent Body); hence it should provide vital information regarding the accretion of the terrestrial planets and the Giant Impact origin of the Moon.

Previously, Humayun and Clayton (1995a) first proposed to use the isotopes of potassium as a tool to study this volatile element depletion. The important questions such as the site and processes responsible for the loss of $\mathrm{K}$ and other volatile elements could potentially be answered by the isotopic fractionation of $\mathrm{K}$ isotopes associated with this loss. They predicted that a Rayleigh style partial evaporation would induce a large $\mathrm{K}$ isotope fractionation, however, no detectable $\mathrm{K}$ isotopic fractionation between terrestrial samples, lunar rocks and meteorites has been observed in their studies. These measurements of $\mathrm{K}$ isotopes were conducted on an ion microprobe and their best analytical uncertainty is 0.5 per mil for the ${ }^{41} \mathrm{~K} /{ }^{39} \mathrm{~K}$ ratio (Humayun and Clayton, 1995b). Potassium isotope studies with Thermal Ionization Mass Spectrometry (TIMS) instruments prior to Humayun and Clayton, have even larger uncertainties ( $>1$ per mil; e.g., Garner et al., 1975). Hence, it would be timely and necessary to re-examine the $\mathrm{K}$ isotopic data acquired with the ion microprobe or TIMS two decades ago, and to re-evaluate these potassium isotope measurements with the new generation of Multiple-Collector Inductively Coupled Plasma Mass Spectrometers (MC-ICP-MS). The measurements of K isotopes with ICPMS have been challenging due to large argon-based interferences $\left({ }^{38} \mathrm{Ar}^{1} \mathrm{H}^{+}\right.$and $\left.{ }^{40} \mathrm{Ar}^{1} \mathrm{H}^{+}\right)$ and the large ${ }^{40} \mathrm{Ar}^{+}$peak of the Ar plasma. Basically two methods can be used to alleviate or eliminate this problem: 1) "cold plasma" method: reducing $\mathrm{ArH}^{+}$ions in the plasmas by lower the RF generator power (Jiang et al., 1988; Morgan et al., 2014); and 2) "collision gas" method: dissociating the molecular ions by introducing a collisional gas 
(Feldmann et al., 1999a; Feldmann et al., 1999b; Bourg et al., 2010; Richter et al., 2011; Richter et al., 2014). The "collision gas" method is used in this study.

Recent developments of isotopic studies for other volatile elements also suggest the need to revisit $\mathrm{K}$ isotopes. Chlorine and zinc are both moderately volatile elements like potassium; their $50 \%$ equilibrium condensation temperatures $\left(T_{c}\right)$ at $10^{-4}$ bar from a solar composition gas are $948 \mathrm{~K}, 726 \mathrm{~K}$ and $1006 \mathrm{~K}$, respectively (Lodders, 2003). Both Zn and $\mathrm{Cl}$ isotopes in lunar samples have been reported to be significantly enriched in heavy $\mathrm{Zn}$ and $\mathrm{Cl}$ isotopes (Sharp et al., 2010; Paniello et al., 2012), which conflicts with the result from previous $\mathrm{K}$ isotopes measurements. In addition, the deviations of $\mathrm{Zn}$ and $\mathrm{Cl}$ isotopes of lunar rocks from those of terrestrial samples are explained as either through a fractionation during a global vaporization event or during local volcanic degassing events. New and improved $\mathrm{K}$ isotope measurements are needed in order to reconcile these different explanations, and to compare to the current high-precision isotopic data of $\mathrm{Zn}$ and $\mathrm{Cl}$.

Potassium is a lithophile and moderately volatile element in term of its geochemical and cosmochemical characteristics. Potassium is the eighth most abundant element in the Earth's crust and fifteenth in the bulk Earth. Potassium has only one oxidation state $(+1)$ in silicate rocks. It has two stable isotopes ${ }^{39} \mathrm{~K}(93.2581 \%)$ and ${ }^{41} \mathrm{~K}(6.7302 \%)$, as well as one naturally occurring long half-life $\left(t_{1 / 2}=1.277 \times 10^{9}\right.$ years $)$ radioactive isotope ${ }^{40} \mathrm{~K}$ $(0.0117 \%)$. This radioactive potassium, which generates heat as it decays to ${ }^{40} \mathrm{Ca}$ and ${ }^{40} \mathrm{Ar}$, has long been recognized as one of the major sources (along with $\mathrm{U}$ and $\mathrm{Th}$ ) of internal heating of the Earth (Urey, 1955). High-precision K-Ar and Ar-Ar dating techniques depend on accurate knowledge of the absolute abundance of ${ }^{40} \mathrm{~K}$ (Naumenko et al., 2013). The ${ }^{40} \mathrm{~K}$ abundance is potentially subjected to change if there is $\mathrm{K}$ isotope fractionation between different samples. Studying K isotopes is thus also very important in avoiding systematic inaccuracies in the determination of high (sub-per mille) precision ${ }^{40} \mathrm{~K}-{ }^{40} \mathrm{Ar}-{ }^{40} \mathrm{Ca}$ ages.

Here we report a procedure for precisely and accurately measuring $\mathrm{K}$ isotopes in silicate rocks. We also report data on a few selected terrestrial samples to explore any possible isotopic fractionation of potassium, which has not been reported in the past.

\section{Analytical methods:}

\subsection{Sample description}

Terrestrial samples studied here include two geostandards, the Columbia River continental flood basalt (BCR-2) and a tholeiitic basalt from the Kilauea crater of Hawaii (BHVO-1). These geostandards are prepared and distributed by USGS, and their 
petrography and geochemical compositions have been well studied and documented. We also analyzed a Mid-Ocean Ridge Basalt (MORB) from East Pacific Rise (CHEPR) (Langmuir, 1988). The sylvites used in this study are from Stassfurt, Germany and Carlsbad Potash District, New Mexico, USA. Pacific seawater was collected during the trans-Pacific sections (TPS) cruises (R/V Thomas Thompson) in the summer of 1985 at a depth of $400 \mathrm{~m}$.

In addition to the natural samples, we have also analyzed a series of industrially produced potassium salts/solutions commercially available from companies such as Merck KGaA, Alfa Aesar, High-Purity Standards and SPEX CertiPrep. These potassium samples are widely accessible, and have been used in different laboratories. In order to compare data corrected with different potassium standards in different laboratories, we have thus analyzed these commercially available samples here in this study.

\subsection{Sample preparation and chemical purification of potassium}

All samples but the sylvites and seawater were digested with a CEM MARS 6 microwave digestion system. They were first dissolved in a concentrated $\mathrm{HF} / \mathrm{HNO}_{3} / \mathrm{HCl}$ mixture $(0.5$ $\mathrm{mL} \mathrm{HF}+2 \mathrm{~mL} \mathrm{HNO}_{3}+1 \mathrm{~mL} \mathrm{HCl}$ ) and then dried with heat lamps in an ultrapure nitrogen environment to remove $\mathrm{HF}$. They were then digested again with diluted aqua regia $\left(0.5 \mathrm{~mL} \mathrm{HNO}_{3}+1.5 \mathrm{~mL} \mathrm{HCl}+1 \mathrm{~mL} \mathrm{H}_{2} \mathrm{O}\right)$. The microwave power was set up to $400 \mathrm{~W}$ in order to reach a temperature of $230^{\circ} \mathrm{C}(20$ minutes ramping time +60 minutes holding time +30 minutes cooling time). Sylvites $(\mathrm{KCl})$ were directly dissolved in Milli$\mathrm{Q}$ water and were centrifuged first before dried down. They were repeatedly dissolved in concentrated $\mathrm{HNO}_{3}$ and dried down in order to remove chlorine.

Fully digested samples were dried and then loaded on $13 \mathrm{~mL}$ Bio-Rad AG50W-X8 cation exchange resin (100-200 mesh) chromatography columns in $0.5 \mathrm{~N} \mathrm{HNO}_{3}$. Columns were pre-cleaned with $300 \mathrm{~mL} 4 \mathrm{~N} \mathrm{HCl}$ and conditioned with $50 \mathrm{~mL} 0.5 \mathrm{~N} \mathrm{HNO}_{3}$. Potassium was eluted with $0.5 \mathrm{~N} \mathrm{HNO}_{3}$ and collected at the 180 to $340 \mathrm{~mL}$ cut. The $\mathrm{K}$ purification procedure used here was first established by Strelow et al. (1970) and the same procedure was also used by Humayun and Clayton (1995a, b). Electronic Annex Table EA1 compares the details of the procedures used by this study and by literature. Electronic Annex Fig. EA1 and EA2 show the elution curves for this column. The blank of the column chemistry is $0.82 \mu \mathrm{g}$.

Other than natural samples, we also prepared enriched ${ }^{39} \mathrm{~K}$ and ${ }^{41} \mathrm{~K}$ "spike" standards in order to test the precision of our measurements. We acquired highly enriched ${ }^{39} \mathrm{~K}$ $(99.91 \pm 0.006 \%)$ and ${ }^{41} \mathrm{~K}(99.17 \pm 0.010 \%)$ spikes from Oak Ridge National Laboratory, where they were electromagnetically separated. An OHAUS ${ }^{\circledR}$ Pioneer ${ }^{\text {TM }}$ PA2 14 balance was used to weigh the spike standards at a repeatability of $0.0001 \mathrm{~g}$. The ${ }^{39} \mathrm{~K}$ and ${ }^{41} \mathrm{~K}$ "spike" standards (in chloride form) were directly dissolved in Milli-Q. They were added 
into the "normal" standard Merck Suprapur ${ }^{\circledR}$ to make $\pm 5, \pm 2.5, \pm 1, \pm 0.5, \pm 0.25, \pm 0.1$, $\pm 0.05 \%$ enriched ${ }^{39} \mathrm{~K}$ and ${ }^{41} \mathrm{~K}$ "spike" standards. The uncertainties of the isotopic composition of the gravimetric standards are shown in Table 1.

\subsection{Mass spectrometry}

We use the "collision gas" method to measure $\mathrm{K}$ isotopes that has been pioneered by previous studies (Feldmann et al., 1999a; Feldmann et al., 1999b; Bourg et al., 2010; Richter et al., 2011; Richter et al., 2014). All the samples were analyzed with a GV Instruments (now Thermo) IsoProbe P MC-ICP-MS at Harvard University. The IsoProbe $\mathrm{P}$ is equipped with a hexapole collision gas cell to remove $\mathrm{Ar}^{+}$and $\mathrm{ArH}^{+}$interferences. Sample solutions were introduced into the plasma source via an APEX-IR spray chamber and ACM desolvator system. A $100 \mu \mathrm{L} / \mathrm{min}$ PFA MicroFlow nebulizer was used. Table 2 lists typical instrument settings on the MC-ICP-MS and on the APEX-IR spray chamber. Fig. 1 shows peak scans of potassium isotopes and $\mathrm{Ar}^{+}$and $\mathrm{ArH}^{+}$interferences in either blank or sample solutions. In MC-ICP-MS without a collision gas cell, Ar-hydride ${ }^{40} \mathrm{Ar}^{1} \mathrm{H}^{+}$produce direct inferences on ${ }^{41} \mathrm{~K}$, while the tails of the large ${ }^{40} \mathrm{Ar}^{+}$peak of the $\mathrm{Ar}$ plasma causes indirect effects on the measurement. In this study, by introducing 5 $\mathrm{mL} / \mathrm{min} \mathrm{H}_{2}$ and $1 \mathrm{~mL} / \mathrm{min}$ Ar into the collision gas cell, we can successfully reduce the ${ }^{39} \mathrm{~K}$ (blank), ${ }^{40} \mathrm{Ar}$ and ${ }^{40} \mathrm{Ar}^{1} \mathrm{H}^{+}$signals to $0.024 \mathrm{~V}, 0.005 \mathrm{~V}$ and $0.00001 \mathrm{~V}$, respectively (note: $1 \times 10^{11} \mathrm{Ohm}$ resistors are used here to report voltages; see Fig. 1). Blank solutions were measured immediately before each sample, and blank subtractions were applied. Fig. 1, sample solutions contained about 400-1000 ppb K which yielded $\sim 6$ V intensities for ${ }^{39} \mathrm{~K}$.

The $\mathrm{K}$ isotopic compositions are reported with the conventional delta notation, where

$\delta^{41} \mathrm{~K}=\left(\left[\left({ }^{41} \mathrm{~K} /{ }^{39} \mathrm{~K}\right)_{\text {sample }}\left({ }^{41} \mathrm{~K} /{ }^{39} \mathrm{~K}\right)_{\text {standard }}-1\right] \times 1000\right)$.

The laboratory standard used in this study is Suprapur ${ }^{\circledR} 99.995 \%$ purity potassium nitrate $\left(\mathrm{KNO}_{3}\right)$ bought from Merck $\mathrm{KGaA}$ in 2014 , and we indicate values relative to this

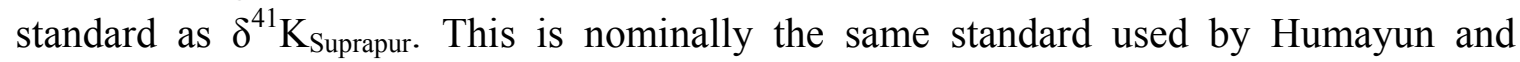
Clayton (1995b), however it is not the same batch. Currently, there is no certified K isotopic standard available. Useful options for standardization currently available appear to be widely available reference basalts such as BCR-2 and BHVO-2 or seawater. We will provide aliquots of the Merck Suprapur ${ }^{\circledR} \mathrm{KNO}_{3}$ used in this study upon request to other laboratories for calibration. Uncertainties are reported as 2SE (standard errors) of repeated measurements (about 10 times or more). As discussed below, we also report measurements relative to the Bulk Silicate Earth (BSE) value, as $\delta^{41} \mathrm{~K}_{\mathrm{BSE}}$. 


\section{Results:}

\subsection{Assessment of the potassium purification with the cation exchange chromatography}

The K purification column chemistry is adopted from Strelow et al. (1970) and Humayun and Clayton (1995a, b), which has been demonstrated as a robust procedure. We tested this column chemistry by passing a mixture of synthetic standards $(200 \mu \mathrm{g} \mathrm{K}+200 \mu \mathrm{g}$ $\mathrm{Na}+200 \mu \mathrm{g} \mathrm{Ca}+200 \mu \mathrm{g} \mathrm{Mg}+200 \mu \mathrm{g} \mathrm{Fe})$ through this column. As seen in Electronic Annex Fig. EA1, potassium can be separated from these major rock elements. Sodium was first eluted through the column and potassium followed with a gap in between. Other major elements such as $\mathrm{Fe}, \mathrm{Mg}$, and $\mathrm{Ca}$, stay in the column during eluting with $0.5 \mathrm{~N}$ $\mathrm{HNO}_{3}$, and only pass through when eluting with the concentrated acid (e.g., $\left.6 \mathrm{~N} \mathrm{HCl}\right)$. The recovery rate of potassium is $>99 \%$. A second test was conducted by passing geostandard BHVO-1 through the column, and the result is shown in Electronic Annex Fig. EA2. Similar to the conclusion drawn from the result of the synthetic standard test, potassium can be effectively separated from all of the major elements in silicate rocks, however, a few trace elements (e.g., $\mathrm{Cr}$ ) can be collected in the potassium cut. To monitor any matrix effect, we analyze the major and trace elemental compositions of the potassium cuts with a Thermo Scientific iCAP Q ICP-MS before measuring the K isotopic compositions with the IsoProbe P. For most the samples in this study, the matrix elements are below $1 \%$ mass of the $\mathrm{K}$ in the solutions. For low-K samples such as CHEPR, the matrix elements are higher than $1 \%$ mass of the $\mathrm{K}$ in the solutions. We passed them through a small column for the further purification (see Electronic Annex Table EA1). All samples measured by the IsoProbe $\mathrm{P}$ for their $\mathrm{K}$ isotopic compositions have lower than $1 \%$ mass of matrix elements compared to the $\mathrm{K}$ in the solutions. As shown in Section 3.3, the matrix effects at $<1 \%$ level are negligible.

\subsection{Evaluation of the potential isotopic fractionation during chemical separation}

To test whether the column chemistry would induce any isotopic fractionation, we have passed the standard Suprapur and the geostandard BHVO-1 three times through the columns for four individual columns. After each column procedure, an aliquot was taken and was measured with the IsoProbe $\mathrm{P}$, and the results are shown in Table 3 . There is no significant fractionation caused by passing samples through the columns. However, only one sample after the third column (BHVO-1-column D-3) shows a slight decrease of the $\delta^{41} \mathrm{~K}$ value compared to others.

We calculated the standard deviation (SD) of the four BHVO-1 splits after first column chemistry (BHVO-1-column A/B/C/D-1), which is $0.033 \%$. The four splits are aliquots from the same digestion of a BHVO-1 standard and they were passing through four 
218 individual columns separately. This standard deviation (0.033\%) represents an estimate

219 of the external reproducibility of our method. The 2SD of four BHVO-1 split is similar to

220 the 2 SE of $\sim 10$ repeated measurements of the same sample, which we have used to report

221 as the analytical uncertainties in the rest of the paper.

\subsection{Assessment of matrix effects during MC-ICP-MS measurements}

As mentioned in Section 3.1, for low-K samples, there are $>1 \%$ mass of $\mathrm{K}$ matrix elements in the final K cuts after the column chemistry. Four matrix elements have been identified in the solutions, which are Al, Ti, V and Cr. Humayun and Clayton (1995b) have also reported that some $\mathrm{Al}, \mathrm{Ti}$ and $\mathrm{Cr}$ as the matrix elements have been eluted with $\mathrm{K}$. We assessed the matrix effect caused by those four elements by doping them into the Suprapur standard. Table 4 and Fig. 2 shows the results of these doped standards measured by IsoProbe P. Aluminum and Ti have small effects, which could lower the $\mathrm{K}$ isotopic compositions by $0.1 \%$ when added in $5 \%$ relative to $\mathrm{K}$. However, vanadium and $\mathrm{Cr}$ have large matrix effects. For example, adding $10 \% \mathrm{Cr}$ (relative to $\mathrm{K}$ ) could change the $\mathrm{K}$ isotopic composition by $0.5 \%$, which is about one order of magnitude higher than the best analytical precision in this study. However, when multiple matrix elements were added into the standards at the same time, the matrix effects are marginal (see Table 4). For any sample with more than $1 \%$ matrix elements in the final $\mathrm{K}$ cuts, we have passed this $\mathrm{K}$ through a second small column to further purify it (see Electronic Annex Table EA1). All the samples measured with the IsoProbe $\mathrm{P}$ have $<1 \%$ matrix in the solutions, which would induce no detectable matrix effects.

\subsection{Potassium isotopic compositions of enriched standards}

To validate the precision and accuracy of the measurements of the MC-ICP-MS in this study, we prepared $( \pm 5, \pm 2.5, \pm 1, \pm 0.5, \pm 0.25, \pm 0.1, \pm 0.05 \%)$ enriched standards by adding highly enriched ${ }^{39} \mathrm{~K}$ and ${ }^{41} \mathrm{~K}$ "spikes" to aliquots from Suprapur $\mathrm{KNO}_{3}$ standard. The gravimetrically enriched standards were measured for $\mathrm{K}$ isotopic composition with the Isoprobe $\mathrm{P}$. The gravimetrically and mass spectrometrically determined $\mathrm{K}$ isotopic compositions are identical within errors except for the $\pm 5 \%$ spiked standards possibly due to memory effects (see Table 1, Fig. 3 and Electronic Annex Fig. EA3). These two $\pm 5 \%$ o spiked standards have the largest fractionations in this study and they are more than ten times larger than the possible fractionation on Earth Humayun and Clayton (1995b). This indicates that our procedure for $\mathrm{K}$ isotope measurements is accurate to distinguish samples with $\mathrm{K}$ isotopic fractionation as small as $0.05 \%$ at best. This is about one order of magnitude improvement compared to previous methods (e.g., Humayun and Clayton, $1995 b)$ that sought to measure variations in natural samples and it is hence suitable for 
natural samples where the largest $\mathrm{K}$ isotopic fractionation is reported below the $0.5 \%$ o level.

\subsection{Potassium isotopic compositions of terrestrial samples}

The three basaltic rocks (BCR-2, BHVO- 1 and CHEPR) all yield the same ${ }^{41} \mathrm{~K} /{ }^{39} \mathrm{~K}$ ratio within errors of each other. Their average value is $-0.479 \pm 0.027 \%$ ( 2 weighted standard deviation), and we use this value to define a Bulk Silicate Earth (BSE) value for potassium isotopes. All the data shown in Table 5 have been presented in both $\delta^{41} \mathrm{~K}_{\text {Suprapur }}$ and $\delta^{41} \mathrm{~K}_{\mathrm{BSE}}$, where $\delta^{41} \mathrm{~K}_{\mathrm{BSE}}=1.000479 \times \delta{ }^{41} \mathrm{~K}_{\text {Suprapur }}+0.479230$. Fig. 4 shows all the data in $\delta^{41} \mathrm{~K}_{\mathrm{BSE}}$. Unlike basalts, the pacific seawater has a significantly higher $\mathrm{K}$ isotopic composition $\left(\delta^{41} \mathrm{~K}_{\mathrm{BSE}}=0.579 \pm 0.065 \%\right.$ ) than that of the igneous rocks in this study. We measured two sylvites from evaporite deposits. The sylvite from New Mexico has an undistinguishable $\mathrm{K}$ isotopic composition $\left(\delta^{41} \mathrm{~K}_{\mathrm{BSE}}=0.510 \pm 0.072 \%\right.$ ) from that of the pacific seawater, while the sylvite from Germany has a higher composition $\left(\delta^{41} \mathrm{~K}_{\mathrm{BSE}}=\right.$ $0.706 \pm 0.030 \%$ ).

Evaporite deposits are the source of mined potassium. Four of the five commercially acquired K standards (Suprapur K, SpecPure K, High-Purity Standards K and SPEX Potassium Carbonate) show similar K isotopic compositions. Only one (SPEX Potassium Chloride) has significantly higher $\mathrm{K}$ isotopic composition than those of the others. Their compositions shown relative either to Suprapur or to BSE values are presented in Table 5 and Fig. 4. The $\mathrm{K}$ isotopic compositions of these commercially available $\mathrm{K}$ standards generally overlap with those of the two sylvites measured in this study; however, they are very different from the $\mathrm{K}$ isotopic composition of rocks. The lack of significant fractionation between sylvite and commercially refined potassium implies that industrial purification processes appear to induce minimal $\mathrm{K}$ isotopic fractionation.

\section{Discussion:}

\subsection{Comparison of the new $K$ isotope measurements with previous data}

Potassium isotopic compositions have been traditionally measured by TIMS and ion microprobe, and no isotopic fractionation has been reported except in lunar regolith samples (Kendall, 1960; Burnett et al., 1966; Barnes et al., 1973; Garner et al., 1975; Church et al., 1976; Begemann and Stegmann, 1976; Stegmann and Begemann, 1979; Humayun and Clayton, 1995b; Humayun and Koeberl, 2004; Herzog et al., 2008). No K isotopic fractionation among terrestrial samples has been detected due to previous large analytical uncertainties (>0.5\%). Recently, Morgan et al. (2013a; 2013b; 2014) first 
presented a $\sim 0.4 \%$ range of $\mathrm{K}$ isotopic fractionation among terrestrial rocks and mineral separates after nearly a decade of inactivity of $\mathrm{K}$ isotope studies. They used a Neptune Plus MC-ICP-MS and reported $<0.05 \%$ analytical uncertainty relative to NIST SRM $999 \mathrm{~b}$, a different potassium chloride standard from the one used in this study and by Humayun and Clayton (1995a, b). The range of the terrestrial potassium isotopic fractionation and analytical uncertainties reported by this group is similar to what reported in this paper, however, no specific data has been published in Morgan et al. (2013a; 2013b; 2014), and no further comparison between these two groups can be made at this time.

\subsection{Potassium isotopic fractionation in igneous rocks}

The magnitude of the equilibrium isotopic fractionation is a function of $1 / T^{2}$. Hightemperature magmatic processes are unlikely to cause large isotopic fractionation for relatively heavy isotopes such as potassium. All the basaltic rocks measured in this study show a uniform potassium isotopic composition $\left(\delta^{41} \mathrm{~K}_{\text {Suprapur }}=-0.479 \pm 0.027 \%\right.$; 2 weighted standard deviation). No potassium isotopic fractionation is observed between samples from different geological settings (continental, plume and mid-ocean ridge). Based on this homogenous $\mathrm{K}$ isotopic composition of all basaltic rocks in this study, here we define a Bulk Silicate Earth value for ${ }^{41} \mathrm{~K} /{ }^{39} \mathrm{~K}$, which is $-0.479 \pm 0.027 \%$ relative to the Suprapur K standard.

Though there is no $\mathrm{K}$ data yet from peridotite xenoliths and from other upper mantle rocks, this BSE value possibly represents a homogenous reservoir for $\mathrm{K}$ isotopes in the Bulk Silicate Earth since there is likely little fractionation between basalts and mantle rocks. Two lines of evidence support this assumption. First, $\mathrm{K}$ is ionically bonded and has only one oxidation state. Elements with strong covalent bonds (e.g., C, O, Si, S) or with multiple valence states $(\mathrm{S}, \mathrm{V}, \mathrm{Cr}, \mathrm{Fe}$ ) exhibit vibrational isotope fractionation effects. Unlike K, Si has a substantial covalent bonding character and Fe is multivalent. It has been shown that $\mathrm{Si}$ and $\mathrm{Fe}$ isotope fractionations between basalts and mantle rocks are at the 0.1 per mil level (e.g., Weyer and Ionov, 2007; Teng et al., 2013; Poitrasson et al., 2013; Craddock et al., 2013; Savage et al., 2013; Savage et al., 2014). Second, K is very incompatible thus it transfers quantitatively to the melt during mantle partial melting. Therefore, the $\mathrm{K}$ isotopic composition of basalts is not expected to be significantly fractionationed relative to their mantle sources. Thus, we propose to use the $\mathrm{K}$ isotopic composition of mantle-derived basalts as a $\mathrm{K}$ isotopic reference for the Bulk Silicate Earth in comparison to sedimentary rocks and materials from other planets, which may be analyzed with higher precision in the future. 
There is no $\mathrm{K}$ isotopic fractionation between igneous rocks found in this study, but we note that more evolved igneous rocks such as pegmatites seem to have large $\mathrm{K}$ isotopic fractionation compared to this Bulk Silicate Earth value (Morgan et al., 2014). However, these results need to be further confirmed and the mechanism needs to be investigated to explain such large fractionation in pegmatite samples.

\subsection{Potassium isotopic fractionation in seawater and marine evaporites}

In seawater, $\mathrm{K}$ is the sixth most abundant element. Its concentration is very constant in various oceans, averaging at $399 \mathrm{ppm}$ with a range between 393 and 405 ppm (Culkin and Cox, 1966; Riley and Tongudai, 1967). In contrast, the average K concentration in rivers is significantly lower (1.3ppm, Lehr and Keeley, 2005). The residence time for $\mathrm{K}$ in seawater is 11 million years (Goldberg, 1961). Our measured value of potassium isotopic composition of Pacific seawater is $\delta^{41} \mathrm{~K}_{\mathrm{BSE}}=0.579 \pm 0.065 \%$, which is significantly higher than those of all the igneous rocks measured in this study. This result is similar (in both the magnitude and direction of fractionation) to what was reported by Morgan et al. (2013a; 2013b; 2014). Lithium isotopes have been recently developed as a tool to reconstruct the Li cycle in ocean and to study the silicate and reverse weathering (Misra and Froelich, 2012). The mechanism of the Li isotopic fractionation could be useful to compare to the case of $\mathrm{K}$ isotopes. Chemical weathering can induce large $\mathrm{Li}$ isotopic fractionations in sediments, and consequently the Li dissolved in the water is different from the Li isotopic composition of the igneous rocks as observed (Huh et al., 1998; Huh et al., 2001). The significantly enriched heavy $\mathrm{K}$ isotopes in the seawater compared to that of BSE is likely due to a similar mechanism. However, the reservoir of light $\mathrm{K}$ isotopes and how seawater evolves to a heavier $\mathrm{K}$ isotopic composition than igneous rocks, still needs to be further investigated.

Sylvite $(\mathrm{KCl})$ is the major evaporite mineral for potassium. The two sylvite samples are from potash deposits in the Carlsbad potash district, New Mexico and Stassfurt, Germany. They were formed as evaporite deposits of seawater from restricted marine basins (Barker and Austin, 1993). The $\mathrm{K}$ isotopic composition of the Stassfurt sylvite is the heaviest in this study $\left(\delta^{41} \mathrm{~K}_{\mathrm{BSE}}=0.706 \pm 0.030 \%\right.$ ), which is $\sim 0.1 \%$ o higher than that of the seawater and $\sim 0.7 \%$ o higher than the BSE value. The $\mathrm{K}$ isotopic composition of the Carlsbad sylvites is indistinguishable with that of the seawater at the current precision $\left(\delta^{41} \mathrm{~K}_{\mathrm{BSE}}=0.510 \pm 0.072 \%\right.$ o vs. $0.579 \pm 0.065 \%$ ) , however, still much higher than the BSE value. These two marine evaporite sylvites were precipitated from ancient (late Permian) seawaters. Sylvites (and carnallite; $\mathrm{KMgCl}_{3} \cdot 6 \mathrm{H}_{2} \mathrm{O}$ ) were formed in the latest stage of the evaporation after $>94 \%$ water has been removed. Previously, chlorine isotopes have been observed to have large isotopic fractionations along the sequential precipitation of evaporites in a modern saline lake (Luo et al., 2012). The $\sim 0$ to $0.1 \%$ potassium isotope 
fractionation measured in sylvites relative to the seawater is possibly due to equilibrium/kinetic fractionation between the brine and precipitates during the evaporation process.

\subsection{Implication for K-Ca-Ar chronology}

The existence of the measurable $\mathrm{K}$ isotope fractionations between terrestrial samples would also have potential impact on the ultra-precise K-Ca-Ar chronology studies in the future. Even though, at the current precision, K-Ar dating does not need to consider this up-to- $0.5 \%$ fractionation in ${ }^{41} \mathrm{~K} /{ }^{39} \mathrm{~K}$ ratio due to a much larger uncertainty in Ar isotopic measurements. With improvement of such measurement, eventually it will be important to also determine the ${ }^{41} \mathrm{~K} /{ }^{39} \mathrm{~K}$ variations, as these will affect the estimate of the absolute ${ }^{40} \mathrm{~K}$ abundance in samples.

\section{Conclusions:}

In this study, we present a method for the high-precision $\mathrm{K}$ isotope measurement with a multiple-collector inductively coupled plasma mass spectrometer equipped with a hexapole collision gas cell. Three basaltic rocks (a continental basalt, a plume basalt and a mid-ocean ridge basalt) were found to have the same $\mathrm{K}$ isotopic composition, defining a Bulk Silicate Earth (BSE) value $(-0.479 \pm 0.027 \%$ o relative to the standard Suprapur). Evaporite sylvites, and seawater are significant higher than the BSE value. This is the first time, to our knowledge, that significant $\mathrm{K}$ isotope fractionations among terrestrial samples have been observed. Potassium isotopes have the potential to be a new tool to study chemical weathering and other low-temperature geochemical processes. It is also important for the very high precision $\mathrm{K}-\mathrm{Ca}-\mathrm{Ar}$ chronology. At last, it is possible in the future to study the origin of volatile depletion in the Moon, Earth and other inner solar system bodies (e.g., 4 Vesta).

\section{Acknowledgements:}

This work was funded by the NASA Emerging Worlds program (NNX15AH66G). K.W. appreciates the financial support from the Harvard Origins of Life Initiative Postdoctoral Fellowship. The authors would also like to thank Misha Petaev for helpful discussions. Dr. Charles Langmuir is thanked for generously providing the CHEPR sample. Dr. Raquel Alonso-Perez and Mr. Kevin Czaja at Harvard Mineralogical and Geological Museum are thanked for providing the two sylvite samples. The enriched ${ }^{39} \mathrm{~K}$ and ${ }^{41} \mathrm{~K}$ isotopes used in this research were supplied by the United States Department of Energy 
398 Office of Science by the Isotope Program in the Office of Nuclear Physics. We thank 399 Drs. Igor Villa and John Christensen for thorough and helpful reviews. We thank the 400 associate editor Dr. Munir Humayun for the constructive comments and prompt handling 401 of the manuscript.

402

403 


\section{References}

Anders E. and Grevesse N. (1989) Abundances of the elements: Meteoritic and solar. Geochim. Cosmochim. Acta 53, 197-214.

Arevalo R., McDonough W. F. and Luong M. (2009) The K/U ratio of the silicate Earth: Insights into mantle composition, structure and thermal evolution. Earth Planet. Sci. Lett. 278, 361-369.

Barker J. M. and Austin G. S. (1993) Economic geology of the Carlsbad potash district, New Mexico. In New Mexico Geological Society Fall Field Conference Guidebook pp. 283-291.

Barnes I. L., Garner E. L., Gramlich J. W., Machlan L. A., Moody J. R., Moore L. J., Murphy T. J. and Shields W. R. (1973) Isotopic abundance ratios and concentrations of selected elements in some Apollo 15 and Apollo 16 samples. Proc. Lunar Sci. Conf. 4.

Begemann F. and Stegmann W. (1976) Implications from the absence of a $41 \mathrm{~K}$ anomaly in an Allende inclusion. Nature 259, 549-550.

Bourg I. C., Richter F. M., Christensen J. N. and Sposito G. (2010) Isotopic mass dependence of metal cation diffusion coefficients in liquid water. Geochim. Cosmochim. Acta 74, 2249-2256.

Burnett D. S., Lippolt H. J. and Wasserburg G. J. (1966) The relative isotopic abundance of K 40 in terrestrial and meteoritic samples. J. Geophys. Res. 71, 1249-1269.

Church S. E., Tilton G. R. and Wright J. E. (1976) Volatile Element Depletion and 39K/41K Fractionation in Lunar Soils. Abstr. Lunar Planet. Sci. Conf. 7.

Craddock P. R., Warren J. M. and Dauphas N. (2013) Abyssal peridotites reveal the near-chondritic Fe isotopic composition of the Earth. Earth Planet. Sci. Lett. 365, 63-76.

Culkin F. and Cox R. A. (1966) Sodium, potassium, magnesium, calcium and strontium in sea water. Deep. Res. 13, 789-804.

Feldmann I., Jakubowski N. and Stuewer D. (1999a) Application of a hexapole collision and reaction cell in ICP-MS Part I: Instrumental aspects and operational optimization. Fresenius. J. Anal. Chem. 365, 415-421.

Feldmann I., Jakubowski N., Thomas C. and Stuewer D. (1999b) Application of a hexapole collision and reaction cell in ICP-MS Part II: Analytical figures of merit and first applications. Fresenius. J. Anal. Chem. 365, 422-428.

Garner E. L., Machlan L. A. and Barnes I. L. (1975) The isotopic composition of lithium, potassium, and rubidium in some Apollo 11, 12, 14, 15, and 16 samples. Proc. Sixth Lunar Sci. Conf., 1845-1855.

Goldberg E. D. (1961) Chemical and mineralogical aspects of deep-sea sediments. Phys. Chem. Earth 4, 281-302.

Halliday A. N. and Porcelli D. (2001) In search of lost planets - the paleocosmochemistry of the inner solar system. Earth Planet. Sci. Lett. 192, 545-559.

Herzog G. F., Alexander C. M. O., Berger E. L., Delaney J. S. and Glass B. P. (2008) Potassium isotope abundances in Australasian tektites and microtektites. Meteorit. Planet. Sci. Arch. 43, 1641-1657.

Huh Y., Chan L.-H. and Edmond J. M. (2001) Lithium isotopes as a probe of weathering processes: Orinoco River. Earth Planet. Sci. Lett. 194, 189-199.

Huh Y., Chan L.-H., Zhang L. and Edmond J. M. (1998) Lithium and its isotopes in major world rivers: implications for weathering and the oceanic budget. Geochim. Cosmochim. Acta 62, 2039-2051.

Humayun M. and Cassen P. (2000) Processes Determining the Volatile Abundances of the Meteorites and Terrestrial Planets. In Origin of the Marth and moon (eds. R. M. Canup and K. Righter). University of Arizona Press, Tucson. 
Humayun M. and Clayton R. N. (1995a) Potassium isotope cosmochemistry - genetic-implications of volatile element depletion. Geochim. Cosmochim. Acta 59, 2131-2148.

Humayun M. and Clayton R. N. (1995b) Precise determination of the isotopic composition of potassium: Application to terrestrial rocks and lunar soils. Geochim. Cosmochim. Acta 59, 2115-2130.

Humayun M. and Koeberl C. (2004) Potassium isotopic composition of Australasian tektites. Meteorit. Planet. Sci. 39, 1509-1516.

Jiang S. J., Houk R. S. and Stevens M. A. (1988) Alleviation of overlap interferences for determination of potassium isotope ratios by inductively coupled plasma mass spectrometry. Anal. Chem. 60, 12171221.

Kendall B. R. F. (1960) Isotopic Composition of Potassium. Nature 186, 225-226.

Langmuir C. H. (1988) Petrology Data Base. In East Pacific Rise Data Synthesis Final Report (ed. S. Tighe). Joint Oceanogr. Inst., Washington, DC.

Lehr J. H. and Keeley J. eds. (2005) Water Encyclopedia., John Wiley \& Sons, Inc., Hoboken, NJ, USA.

Lodders K. (2003) Solar system abundances and condensation temperatures of the elements. Astrophys. J. 591, 1220-1247.

Luo C., Xiao Y., Ma H., Ma Y., Zhang Y. and He M. (2012) Stable isotope fractionation of chlorine during evaporation of brine from a saline lake. Chinese Sci. Bull. 57, 1833-1843.

Misra S. and Froelich P. N. (2012) Lithium isotope history of Cenozoic seawater: changes in silicate weathering and reverse weathering. Science 335, 818-23.

Morgan L. E., Higgins J., Davidheiser-Kroll B., Lloyd N., Faithfull J. and Ellam R. (2014) Potassium isotope geochemistry and magmatic processes. In Goldschmidt Conference

Morgan L. E., Lloyd N., Ellam R., Simon J. and Tappa M. (2013a) Potassium Stable Isotopic Compositions Measured by High-Resolution MC-ICP-MS. In Goldschmidt Conference

Morgan L. E., Tappa M., Ellam R., Mark D., Higgins J. and Simon J. (2013b) Potassium isotopic compositions of NIST potassium standards and 40Ar/39Ar mineral standards. In American Geophysical Union Fall Meeting

Naumenko M. O., Mezger K., Nägler T. F. and Villa I. M. (2013) High precision determination of the terrestrial 40K abundance. Geochim. Cosmochim. Acta 122, 353-362.

Paniello R. C., Day J. M. D. and Moynier F. (2012) Zinc isotopic evidence for the origin of the Moon. Nature 490, 376-9.

Poitrasson F., Delpech G. and Grégoire M. (2013) On the iron isotope heterogeneity of lithospheric mantle xenoliths: implications for mantle metasomatism, the origin of basalts and the iron isotope composition of the Earth. Contrib. to Mineral. Petrol. 165, 1243-1258.

Richter F. M., Bruce Watson E., Chaussidon M., Mendybaev R., Christensen J. N. and Qiu L. (2014) Isotope fractionation of $\mathrm{Li}$ and $\mathrm{K}$ in silicate liquids by Soret diffusion. Geochim. Cosmochim. Acta 138, 136-145.

Richter F. M., Mendybaev R. A., Christensen J. N., Ebel D. and Gaffney A. (2011) Laboratory experiments bearing on the origin and evolution of olivine-rich chondrules. Meteorit. Planet. Sci. 46, 1152-1178.

Riley J. P. and Tongudai M. (1967) The major cation/chlorinity ratios in sea water. Chem. Geol. 2, 263269.

Savage P. S., Armytage R. M. G., Georg R. B. and Halliday A. N. (2014) High temperature silicon isotope geochemistry. Lithos 190-191, 500-519.

Savage P. S., Georg R. B., Williams H. M. and Halliday A. N. (2013) Silicon isotopes in granulite xenoliths: Insights into isotopic fractionation during igneous processes and the composition of the 
deep continental crust. Earth Planet. Sci. Lett. 365, 221-231.

492
Sharp Z. D., Shearer C. K., McKeegan K. D., Barnes J. D. and Wang Y. Q. (2010) The chlorine isotope composition of the Moon and implications for an anhydrous mantle. Science (80-. ). 329, 1050-1053.

Stegmann W. and Begemann F. (1979) Allende meteorite - old age but normal isotopic composition of potassium. Nature 282, 290-291.

Strelow E. W. E., Von S. Toerien F. and Weinert C. H. S. W. (1970) Accurate determination of traces of sodium and potassium in rocks by ion exchange followed by atomic absorption spectroscopy. Anal. Chim. Acta 50, 399-405.

Taylor S. R. (1982) Lunar and terrestrial crusts: a constrast in origin and evolution. Phys. Earth Planet. Inter. 29, 233-241.

Teng F.-Z., Dauphas N., Huang S. and Marty B. (2013) Iron isotopic systematics of oceanic basalts. Geochim. Cosmochim. Acta 107, 12-26.

Urey H. C. (1955) The cosmic abundances of potassium, uranium, and thorium and the heat balances of the Earth, the Moon, and Mars. Proc. Natl. Acad. Sci. 41, 127-144.

Wasserburg G. J., Macdonald G. J., Hoyle F. and Fowler W. A. (1964) Relative Contributions of Uranium, Thorium, and Potassium to Heat Production in the Earth. Science (80-. ). 143, 465-7.

Weyer S. and Ionov D. A. (2007) Partial melting and melt percolation in the mantle: The message from Fe isotopes. Earth Planet. Sci. Lett. 259, 119-133. 
Table 1. Gravimetric and MC-ICP-MS Results of Enriched Isotope Standards.

\begin{tabular}{|c|c|c|c|c|c|c|c|}
\hline Target & $\delta^{41} K_{\text {Suprapur }}(\% o)$ & & $2 \sigma$ & $\delta^{41} K_{\text {Suprapur }}(\% o)$ & & $2 S E^{a}$ & $n^{b}$ \\
\hline & Gravimetric & & & $M C-I C P-M S$ & & & \\
\hline-5 & -5.10 & \pm & 0.06 & -5.26 & \pm & 0.10 & 10 \\
\hline+5 & 4.99 & \pm & 0.05 & 4.74 & \pm & 0.08 & 10 \\
\hline-2.5 & -2.48 & \pm & 0.04 & -2.42 & \pm & 0.12 & 8 \\
\hline+2.5 & 2.48 & \pm & 0.04 & 2.42 & \pm & 0.14 & 8 \\
\hline-1 & -1.00 & \pm & 0.02 & -1.06 & \pm & 0.16 & 6 \\
\hline+1 & 1.00 & \pm & 0.02 & 1.00 & \pm & 0.18 & 6 \\
\hline-0.5 & -0.50 & \pm & 0.01 & -0.51 & \pm & 0.06 & 10 \\
\hline+0.5 & 0.50 & \pm & 0.01 & 0.51 & \pm & 0.06 & 10 \\
\hline-0.25 & -0.25 & \pm & 0.01 & -0.24 & \pm & 0.07 & 9 \\
\hline+0.25 & 0.25 & \pm & 0.01 & 0.26 & \pm & 0.05 & 9 \\
\hline-0.1 & -0.099 & \pm & 0.003 & -0.11 & \pm & 0.02 & 10 \\
\hline+0.1 & 0.099 & \pm & 0.002 & 0.10 & \pm & 0.02 & 10 \\
\hline-0.05 & -0.052 & \pm & 0.001 & -0.08 & \pm & 0.06 & 9 \\
\hline+0.05 & 0.049 & \pm & 0.001 & 0.05 & \pm & 0.03 & 8 \\
\hline
\end{tabular}

${ }^{\text {a }}$ Standard errors ( $\mathrm{SE}=$ standard deviation divided by the square root of the total number of measurements).

${ }^{\mathrm{b}}$ Number of measurements. 
Table 2. Typical Instrument Settings on the IsoProbe P MC-ICP-MS and APEX IR

\begin{tabular}{lc}
\hline$M C$-ICP-MS parameters & $1350 \mathrm{~W}$ \\
RF power & $13 \mathrm{~L} / \mathrm{min}$ \\
Cool gas flow rate & $1.1 \mathrm{~L} / \mathrm{min}$ \\
Intermediate gas flow rate & $0.9 \mathrm{~L} / \mathrm{min}$ \\
Sample gas flow rate & $6000 \mathrm{~V}$ \\
High voltage & $\mathrm{H}_{2}: 5 \mathrm{~mL} / \mathrm{min}$ \\
Hexapole Gases & Ar: $1 \mathrm{~mL} / \mathrm{min}$ \\
& $10000 \mathrm{~ms}$ \\
Integration time & 30 \\
Number of cycles & 1 \\
Number of blocks & $-300 \mathrm{~V}$ \\
Extraction voltage & Soft \\
Hard/soft extraction & \\
& \\
APEX IR parameters & Chiller: $2^{\circ} \mathrm{C}$ \\
Sample uptake rate & $100 \mu \mathrm{L} / \mathrm{min}$ \\
Spray chamber temperature & \\
&
\end{tabular}




\section{Table 3. Potassium Isotopic Compositions of Analytical Tests of the Column Chemistry}

\begin{tabular}{|c|c|c|c|c|}
\hline & $\delta^{41} K_{\text {Suprapur }}(\%)$ & & $2 S E^{a}$ & $n^{b}$ \\
\hline \multicolumn{5}{|l|}{ Without passing chemistry } \\
\hline Suprapur K-0 & 0.021 & \pm & 0.075 & 10 \\
\hline \multicolumn{5}{|l|}{ First pass chemistry } \\
\hline Suprapur K-column A-1 & 0.017 & \pm & 0.037 & 10 \\
\hline Suprapur K-column B-1 & -0.031 & \pm & 0.031 & 10 \\
\hline \multicolumn{5}{|l|}{ Second pass chemistry } \\
\hline Suprapur K-column A-2 & 0.014 & \pm & 0.046 & 10 \\
\hline Suprapur K-column B-2 & 0.028 & \pm & 0.039 & 10 \\
\hline \multicolumn{5}{|l|}{ Third pass chemistry } \\
\hline Suprapur K-column A-3 & -0.047 & \pm & 0.053 & 9 \\
\hline Suprapur K-column B-3 & -0.007 & \pm & 0.034 & 9 \\
\hline \multicolumn{5}{|l|}{ First pass chemistry } \\
\hline BHVO-1-column A-1 & -0.462 & \pm & 0.079 & 17 \\
\hline BHVO-1-column B-1 & -0.479 & \pm & 0.051 & 17 \\
\hline BHVO-1-column C-1 & -0.504 & \pm & 0.094 & 25 \\
\hline BHVO-1-column D-1 & -0.425 & \pm & 0.075 & 25 \\
\hline \multicolumn{5}{|l|}{ Second pass chemistry } \\
\hline BHVO-1-column A-2 & -0.589 & \pm & 0.106 & 11 \\
\hline BHVO-1-column B-2 & -0.545 & \pm & 0.071 & 9 \\
\hline BHVO-1-column C-2 & -0.516 & \pm & 0.068 & 12 \\
\hline BHVO-1-column D-2 & -0.568 & \pm & 0.076 & 10 \\
\hline \multicolumn{5}{|l|}{ Third pass chemistry } \\
\hline BHVO-1-column A-3 & -0.505 & \pm & 0.051 & 10 \\
\hline BHVO-1-column B-3 & -0.475 & \pm & 0.093 & 8 \\
\hline BHVO-1-column D-3 & -0.603 & \pm & 0.038 & 9 \\
\hline
\end{tabular}

\footnotetext{
${ }^{\text {a }}$ Standard errors $(\mathrm{SE}=$ standard deviation divided by the square root of the total number of measurements).

${ }^{\mathrm{b}}$ Number of measurements.
} 


\section{Table 4. Potassium Isotopic Compositions of Standards Doped With Potential Residual Matrix Elements}

\begin{tabular}{|c|c|c|c|c|}
\hline Matrix Elements & $\delta^{41} K_{\text {Suprapur }}(\% o)$ & & $2 S E^{a}$ & $n^{b}$ \\
\hline $2 \% \mathrm{Al}$ & -0.038 & \pm & 0.046 & 9 \\
\hline $5 \% \mathrm{Al}$ & -0.013 & \pm & 0.069 & 10 \\
\hline $10 \% \mathrm{Al}$ & -0.057 & \pm & 0.058 & 7 \\
\hline $20 \% \mathrm{Al}$ & -0.060 & \pm & 0.077 & 7 \\
\hline $50 \% \mathrm{Al}$ & -0.131 & \pm & 0.108 & 10 \\
\hline $2 \% \mathrm{Ti}$ & 0.004 & \pm & 0.042 & 9 \\
\hline $5 \% \mathrm{Ti}$ & -0.030 & \pm & 0.108 & 7 \\
\hline $10 \% \mathrm{Ti}$ & -0.086 & \pm & 0.050 & 10 \\
\hline $20 \% \mathrm{Ti}$ & -0.124 & \pm & 0.036 & 9 \\
\hline $50 \% \mathrm{Ti}$ & -0.172 & \pm & 0.042 & 8 \\
\hline $1 \% \mathrm{~V}$ & -0.024 & \pm & 0.052 & 8 \\
\hline $2 \% \mathrm{~V}$ & -0.109 & \pm & 0.059 & 10 \\
\hline $5 \% \mathrm{~V}$ & -0.219 & \pm & 0.071 & 10 \\
\hline $10 \% \mathrm{~V}$ & -0.373 & \pm & 0.085 & 9 \\
\hline $20 \% \mathrm{~V}$ & -0.814 & \pm & 0.144 & 6 \\
\hline $50 \% \mathrm{~V}$ & -2.021 & \pm & 0.045 & 6 \\
\hline $1 \% \mathrm{Cr}$ & -0.066 & \pm & 0.076 & 8 \\
\hline $2 \% \mathrm{Cr}$ & -0.078 & \pm & 0.055 & 10 \\
\hline $5 \% \mathrm{Cr}$ & -0.244 & \pm & 0.072 & 9 \\
\hline $10 \% \mathrm{Cr}$ & -0.500 & \pm & 0.081 & 9 \\
\hline $20 \% \mathrm{Cr}$ & -0.731 & \pm & 0.042 & 8 \\
\hline $50 \% \mathrm{Cr}$ & -2.096 & \pm & 0.217 & 10 \\
\hline $0.5 \%$ Each Mixture ${ }^{c}$ & -0.032 & \pm & 0.102 & 8 \\
\hline 1\% Each Mixture & -0.086 & \pm & 0.084 & 7 \\
\hline 2\% Each Mixture & -0.033 & \pm & 0.048 & 9 \\
\hline 5\% Each Mixture & -0.067 & \pm & 0.042 & 9 \\
\hline
\end{tabular}

${ }^{a}$ Standard errors ( $\mathrm{SE}=$ standard deviation divided by the square root of the total number of measurements).

${ }^{\mathrm{b}}$ Number of measurements.

${ }^{\mathrm{c}}$ Mixture of $\mathrm{Al}, \mathrm{Ti}, \mathrm{V}$ and $\mathrm{Cr}$ (percentage is for each element). 
Table 5. Potassium Isotopic Compositions of Terrestrial Samples

\begin{tabular}{|c|c|c|c|c|c|c|c|c|c|}
\hline Sample & Description & Location & Weight (mg) & {$[K](p p m)$} & $\begin{array}{r}\delta^{41} K_{\text {Suprapur }} \\
\text { (\%o) }\end{array}$ & $\begin{array}{r}\delta^{41} K_{B S E} \\
(\% o)\end{array}$ & & $2 S E^{a}$ & $n^{b}$ \\
\hline \multicolumn{10}{|l|}{ NATURAL SAMPLES } \\
\hline BCR-2 & Basalt & Portland, Oregon & 12.3 & 14024.0 & -0.474 & 0.005 & \pm & 0.086 & 12 \\
\hline BHVO-1 & Basalt & Hawaii & 41.8 & & -0.467 & 0.012 & \pm & 0.038 & 84 \\
\hline CHEPR & Basalt & East Pacific Rise & 46.5 & 2407.6 & -0.496 & -0.017 & \pm & 0.044 & 19 \\
\hline Ave. Basalts & & & & & -0.479 & $0.000^{c}$ & \pm & 0.027 & 115 \\
\hline Pacific Sea Water & Sea Water & TPS $24^{\circ} \mathrm{N}$, Station $35,400 \mathrm{~m}$ & 1493.0 & 337.2 & 0.100 & 0.579 & \pm & 0.065 & 22 \\
\hline Sylvite-1 & Sylvite & Stassfurt, Germany & & & 0.227 & 0.706 & \pm & 0.030 & 14 \\
\hline Sylvite-2 & Sylvite & $\begin{array}{c}\text { Carlsbad Potash District, } \\
\text { New Mexico }\end{array}$ & & & 0.031 & 0.510 & \pm & 0.072 & 8 \\
\hline \multicolumn{10}{|l|}{ SYNTHETIC SAMPLES } \\
\hline Suprapur K & Merck KGaA & & & & -0.009 & 0.470 & \pm & 0.014 & 16 \\
\hline SpecPure K & Alfa Aesar & & & & -0.006 & 0.473 & \pm & 0.016 & 33 \\
\hline High-Purity Standards K & High-Purity Standards & & & & -0.094 & 0.385 & \pm & 0.051 & 13 \\
\hline $\begin{array}{l}\text { SPEX Potassium } \\
\text { Chloride }\end{array}$ & SPEX CertiPrep & & & & 0.384 & 0.863 & \pm & 0.042 & 15 \\
\hline $\begin{array}{c}\text { SPEX Potassium } \\
\text { Carbonate }\end{array}$ & SPEX CertiPrep & & & & 0.022 & 0.501 & \pm & 0.042 & 18 \\
\hline
\end{tabular}

${ }^{a}$ Standard errors ( $\mathrm{SE}=$ standard deviation divided by the square root of the total number of measurements).

${ }^{\mathrm{b}}$ Number of measurements.

${ }^{\mathrm{c}}$ These 84 repeat measurements are the four BHVO-1 A, B, C, D after one time column chemistry from Table 3.

${ }^{\mathrm{d}}$ The $\delta^{41} K_{B S E}$ of the average of basalt is zero by definition. 


\section{Figure Caption:}

Fig. 1. Scans of peak shapes of potassium isotopes and argon with the IsoProbe P MCICP-MS. Three Faraday cups (H1, AX and L2) were used. All the measurements were done at the peak centers for standards, samples and blanks. The typical intensities for 400 ppb standard and blank $\left(2 \% \mathrm{HNO}_{3}\right)$ solutions are displayed in the figure. For all three collectors, $1 \times 10^{11}$ Ohm resistors are used.

Fig. 2. Potassium isotopic compositions of standards doped with potential residual matrix elements (Al, Ti, V and Cr). Substantial amounts of these matrix elements were found in $\mathrm{K}$ cuts of low-K samples. A second small column was added to insure that all matrix elements are below $0.5 \%$ (relative to $\mathrm{K}$ ) levels before mass spectrometer measurements of the $\mathrm{K}$ isotopic composition.

Fig. 3. Comparison of the gravimetric and IsoProbe P results of the enriched isotope standards. (A) panel displays all the enriched isotope standards. (B) panel displays an enlarged area ( -0.3 to $0.3 \%$ ) of the (A) panel. Note that that $0.05 \%$ is a resolvable number. All the data fall the 1:1 line where the IsoProbe $\mathrm{P}$ measured values equal with the gravimetric values. The error bars are smaller than the sizes of the symbols if they are not shown. (C) panel displays the difference between the gravimetric and MC-ICPMS measurements. The black symbols represent zero (the target value) with error bars of gravimetric measurements. The red symbols represent the difference between the gravimetric and MC-ICPMS measurements with error bars considering both. Only the +5 $\%$ gravimetric standard deviates by more than $0.05 \%$ (taking into account the uncertainties) from the MC-ICPMS measurements.

Fig. 4. The potassium isotopic compositions of terrestrial samples. The shaded area shows the average value ( \pm 2 standard deviation) of three basalts from various tectonic settings (continental, plume and mid-ocean ridge). All igneous rocks are represented with red circle symbols, seawater in green triangle symbols, evaporite sylvites in blue square symbols, and synthetic samples in purple diamond symbols. All the values here are shown relative to the Bulk Silicate Earth (BSE) value, where $\delta^{41} \mathrm{~K}_{\mathrm{BSE}}=1.000479 \times$ $\delta^{41} \mathrm{~K}_{\text {Suprapur }}+0.479230$. 

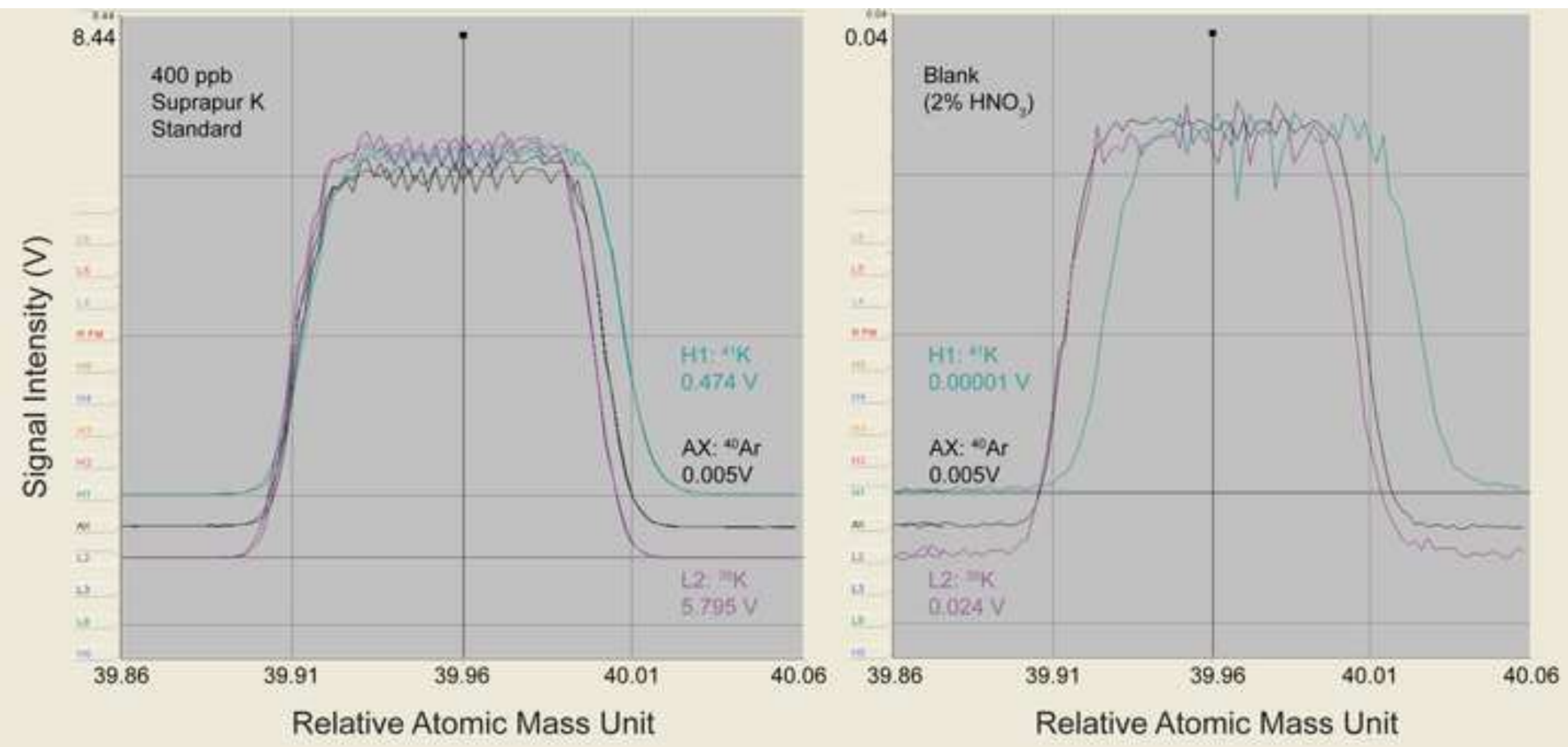


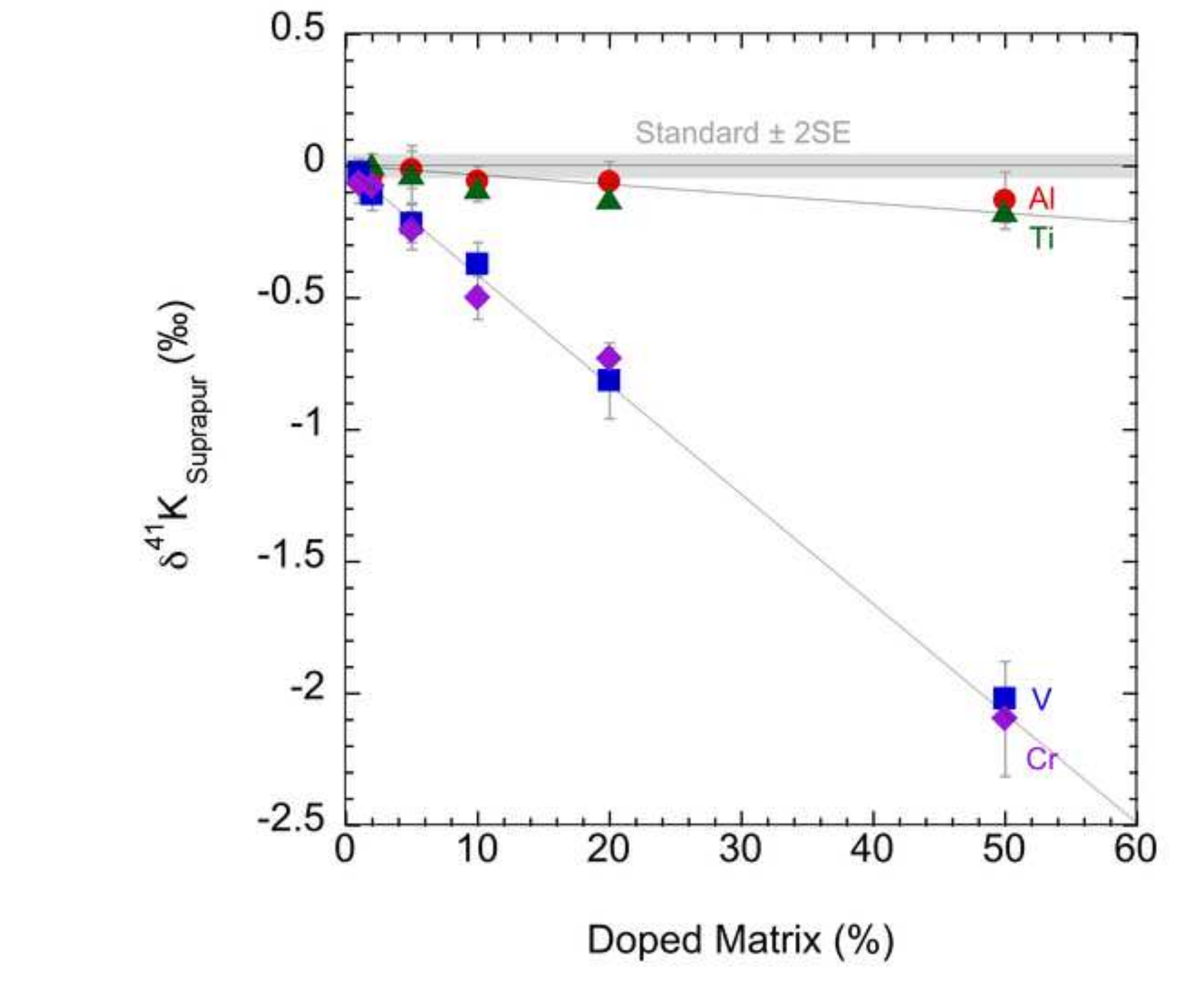

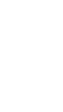



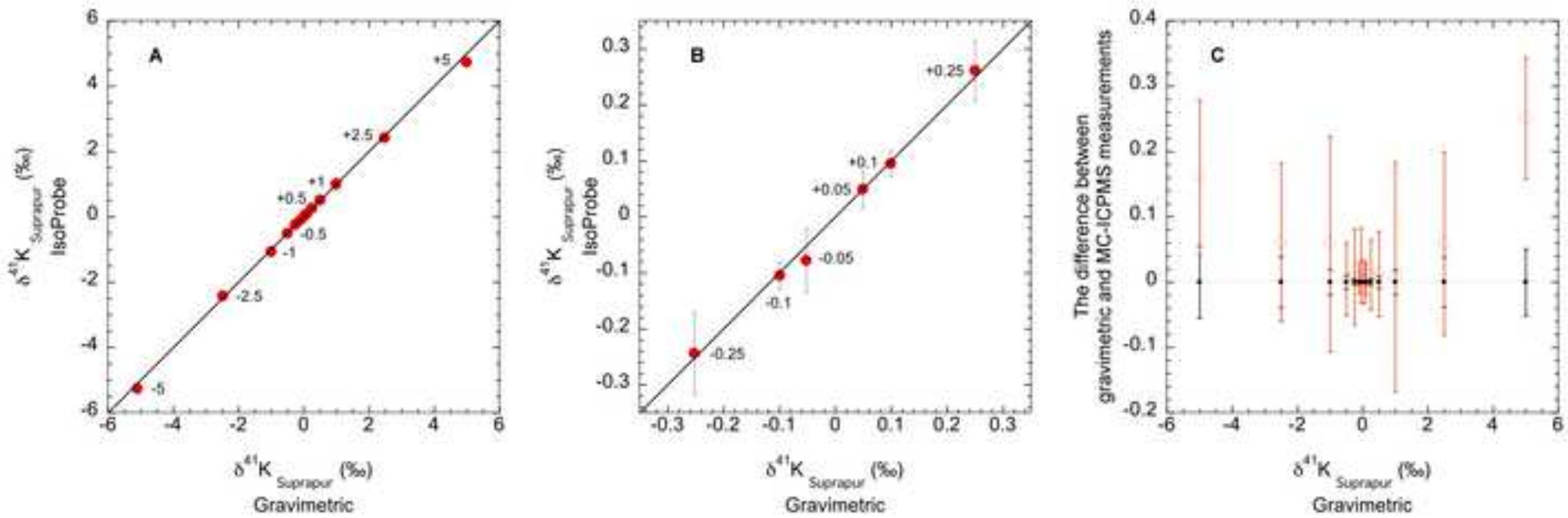


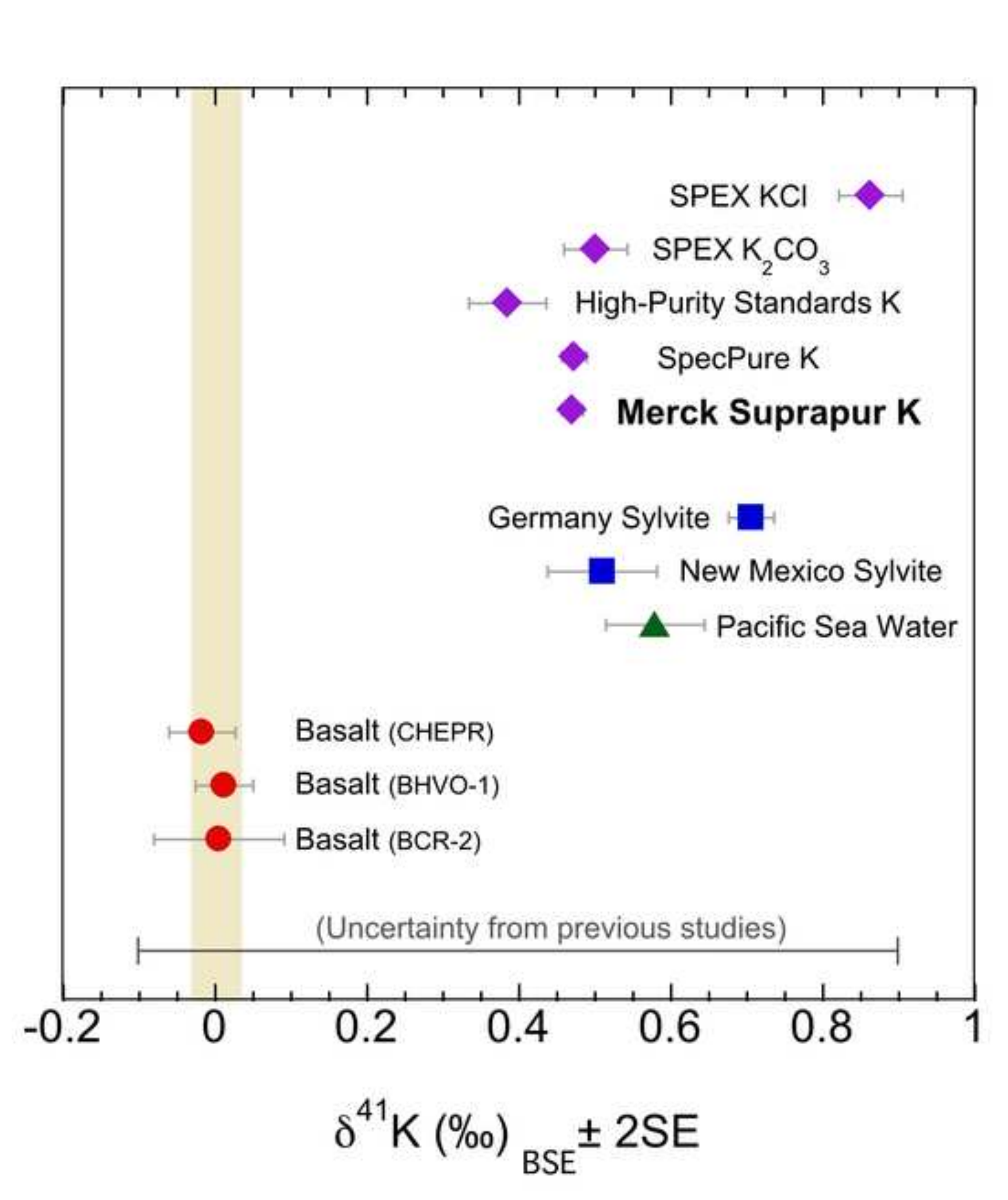

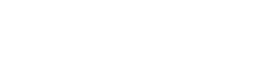
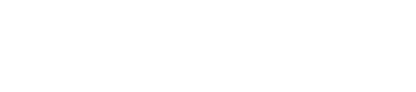

-

-

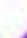

SPEXKCI

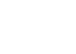

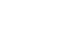

.

.

.

(

. 